\title{
Building Resilience of the Christian Education Teachers in Developing Students Potentials in Digital Era
}

\author{
Yanice Janis $^{1}$, Rolina A.E. Kaunang ${ }^{2}$ \\ ${ }^{1,2}$ IAKN Manado, Manado, Indonesia \\ \{yanicejanis@gmail.com¹, rolina.ae.kaunang@gmail.com² ${ }^{2}$,
}

\begin{abstract}
The Christian Education teachers are required to be able to use technological information in learning not only to create brilliant students intellectually but also to shape the good character of students. Therefore, they must master the skills of the 21 st century learning so that they can answer the needs of students of this era who are excel in technology. Using the theory from International Society for Technology in Education translated by Daryanto and Syaiful Karim, this study aimed to find out the resilence of Christian Education teachers in North Sulawesi, to propose and to implement the resilience of Christian Education teachers in digital era. This study applied descriptive qualitative research method which is also called naturalistic inquiry or naturalistic approach. Based on the research, it showed that the Christian education teachers in North Sulawesi still have the tendency to be trapped in manual learning system which is not relevant anymore with the 21 st century context and they are less competitive and difficult to adapt with the learning demand of the 21 st century.
\end{abstract}

Keywords: Resilience, Christian Education Teacher and Digital Era.

\section{Introduction}

The world's portrait in the 21 st century requires humans to be able to adapt to survive, so does the education as the tool of human civilization. Therefore, it is essential for education to keep innovating and adapting with the 21 st century so that the technology which is the result of education will not be a boomerang to the education itself. I WayanRedhana classifies the 21 st century skills into critical thinking and problem solving, creativity and innovation, collaboration and communication. In line with Chaeruman who argues that the 21 st century requires 3 skills namely, learning and innovating capabilities, media information and technology capabilities, life and carrier capabilities. In contrast, Sujarwo states that education in Indonesia nowadays has not yet a clear direction. Supported by Daryanto and Abdul Karim citatingTrisdiono that the education quality in Indonesia is still considered low because in the beginning of the 21 st century, the human resources are not competitive enough. The teachers incapability adapting with the 21 st century learning results in mistargetting learning practice and failure in answering the students needs. The Christian education teachers in North Sulawesi are expected to be able to adapt with the 21 st century learning to lead students out from mental and moral degradation zone and to enable students taking parts in the world flown by information wave based on technology. 


\section{Research Methodology}

\subsection{The 21st Century Learning - The Resilience of Christian Education Teachers}

Generally, the 21 st century learning problem is also experienced by Christian education teachers in North Sulawesi. They have taught for 1 to 26. It means that teaching experience has been gained from many generations. They said,"It is very different teaching students in the past and in the present time. Students were obedient and easy to be managed back then, but now they are difficult to be directed and advised. They seem impolite and disrespectful to teachers." The internet brings a huge impact, although it is undeniable that internet is indeed facilitating learning in the class. In line with Daryanto and Syaiful Karim who state that the development of the 21 st century is marked with the utilization of technological information resulting in the shift of all life aspects including in learning.

\subsection{The Ability to Facilitate and Inspire the Study and Creativity of Students}

The use of technology as the supporting learning tools is important. Nevertheless, not all schools have the facilitation and not all Christian education teachers can utilize the facilitation due to the weakness of technological literacy. Generally, the Christian education teachers who have taught for more than 10 years face difficulties in using learning supporting tools based on technology. Meanwhile, one of the characteristics of the 21 st century teachers is possesing skills in technological utilization. The characteristic of Christian education teachers in North Sulawesi when teaching is using various methods in learning such as, sharing/discussion, memorizing, providing illustration to the learning practice with bible, tune, and motion. Generally, the technological facilities owned by school to support the 21 st century learning in North Sulawesi are wi-fi, lcd projectors and laptops. Daryanto and Syaiful Karim citating from the International Society for Technology in Education with recommendation to the 21 st century teachers is related to the teachers' ability to facilitate and to inspire the creative study of the students.

\section{Result and Discussion}

\subsection{Designing and Developing Learning Experience and Assessment in Digital Era}

In designing and developing the learning experience and assessment, a teacher needs to prepare tools integrated with digital sources for example in the teaching And learning process using PowerPoint media, the tools needed are a laptop, an LCD projector, a power plug and active speakers. In addition, to complete the lesson materials, the teacher can look for additional information using smartphone through the internet Network. The Christian education teachers in North Sulawesi have different characteristics, for example, some enjoy using the method of movie review but not the others. The movie rebiew method is a learning method directly integrated with the tools and other digital sources. 
Teachers are also need to develop learning environment which is rich in technology to stimulate the curiosity of students and to make them actively participate in composing, organizing, and measuring their own learning development. In the teaching and learning process , Christian education teachers in North Sulawesi stimulate the studrnts by for instance giving a question to the students to be responded then summarized together so that interaction happened in class. Interaction is a primary requirement to teachers and students for the teaching and learning process to be happened. There are some who motivate students by telling them inspirative stories. Such learning experience is considered important to be implemented on students however, teachers in this case have not yet oriented on the maximum technological utilization.

\subsection{Becoming the Model of Studying and Working in Digital Era}

Teachers as guides are supposed to possesed skills more than their students. Based on the interview result with the Christian education teachers, it is indicated that teachers teaching in urban areas are more skillfull in using digital sources, namely, microsoft word, microsoft excel, microsoft power point, photoshop and bible works, while the Christian education teachers in islands and rural areas tend to master only microsoft word application. The capability in mastering technological system is needed by teachers so that they can collaborate with students using digital media to support students' success and innovation.

Besides it can increase the ability to collaborate with students, digital media mastering also helps teachers to be able to communicate their ideas to students, parents and other teachers so that the learning will be more effective and will be continued since it can be accessed anywhere and anytime, for example, by using social media. The Christian education teachers in North Sulawesi have used digital media to communicate with students, parents, and other teachers by using social media application such as, Facebook, WA, Instagram and Messenger.

\subsection{Motivating and Being a Model of Responsibility in Digital Society}

Motivation for students to do tasks with internet reference needs teacher supervision, consideringthe regulations number 28 of 2014 concerning theCopyright which organizes the way of citating others works. Using internet reference enables students to break the ethics code of digital information technology. To anticipate it, the Christian education teachers in North Sulawesi make strategy, for example, at the semester final test, written test avoided, and using oral test by asking students to memorize the Lord's Prayer and the Confession of Faithin Indonesian and English and giving punishments such as returning the work to be corrected by the students. It can be seen that the attitude of the Christian education teachers in North Sulawesi is less relevant in motivating and being the model of responsibility in digital society. Memorizing is not long-lasting and the quality is only on the knowledge level. Teachers are supposed to give example of how to use internet reference, for instance, organizing the citation with students' words, requiring and modelling the writing of the reference (footnotes), and showing them the deterrent effect of disobeying the copyright regulations such as fines and jail punishments.

Subsequently, a teacher motivates and models the responsibility and the social interaction ethics related to the use of technological information. All Christian education teachers in North Sulawesi have been using social media namely, Facebook, WhatsApp, Instagram, Messenger, Google and YouTube. Those social media enable teachers to upload anything they want in form of caption, photos and videos. To serve students in heutagogy era which is 
influenced by technology, it cannot rely entirely on direct meeting, giving assignment and discussion because these things cannot stimulate students to think critically and creatively. Social media can be a learning tool considering this generation is excel in using it.

\subsection{Participating in professional development and leadership}

One of the competencies of Christian Education teachers is leadership. As the learning agent, the Christian education teachers must be able to be the leaders. Consequently, as a leader, they are expected to give contributions on new things related to Christian education learning. Due to the need of teachers' competency development, they are required to participate both in local and global communities in order to find out the application of creative technology in improving learning. Associated with the teachers' profession in the context of adapting with the $21^{\text {st }}$ century learning based on technology, the Christian education teachers in North Sulawesi are not much involved in both local and global communities. Communities joined in by the Christian teachers in North Sulawesi are still in small scale for example, Subject Teacher Discussion Group (MGMP) which is only discussing curriculum and learning devices conformity. In addition, they are also involved in church activities but there are also some teachers who are not involved in any communities. Digital media opens the room for everyone especially for teachers to be involved and participated in a community which can be a media to develop their competencies, for example, the Indonesian teachers association (IGI) community and Teachers of the New Era (Guraru).

In this digital era, the success of learning is inseparable with the influence of the updated technology and information. The mastering of digital media is necessary to utilize many current research results provided by the internet. The Christian education teachers in North Sulawesi admit that they have not yet used research journals in their effort to support the learning to be successful. The learning materials are not only available through books and printed media. The science which is keep developing can be observed by digital media utilization through the research journals. The digital era requires teachers to be able to evaluate and reflect the current researches which can present new issues with recommendation as the materials to support the success of learning. By doing so, the Christian education teachers in the $21^{\text {st }}$ century will keep showing their existences toward the effectivity and vitality of the teacher profession both at school and at environment outside the school.

\section{Conclusion}

The 21 st century learningrequieres teachers to be excellent and skillful using technology. Students nowadays need a leader figure who can be modelled and can provide their learning needs which has switched to the use of digital media. The Christian teachers as facilitators must be able to provide and demonstrate learning media based on technology whether in class meeting or in learning community outside school which can attract students to study and develop potentials. The ability of Christian education teachers to adapt with the 21 st century learning is still less competitive. It is caused by the following. Firstly, the Christian education teachers in North Sulawesi are dominated by $\mathrm{x}$ generation who live in manual system neighborhood. Secondly, the Christian education teachers in North Sulawesi have not yet gotten special training from related agency concerning the learning in digital era. The training needed by the Christian education teachers in digital era context is continually based on 
technology, since education and technology develops every day. Thirdly, the lack of technology facilities at school to support the 21 st learning activities. Fourthly, the Christian education do not have motivation to join with the local and global communities to increase the competence of teacher's profession.

Based on those statements, it is recommended that the related education department is expected to be able to provide the Chrjstian education teachers in facing the 21 st century learning, namely, by conducting continually trainings concerning technology and information. The school leaders are expected to work for it and to facilitate all teachers in the 21 st century learning process, namely by providing school assets such as, wi-fi, lcd projector, laptop, active speakers, current research journal, and supporting books, while the Christian education teachersare expected to improve their skills by learning individually regarding the digital world for example by using up to date science through the current research journals, participating in education seminar/training to increase teachers competencies in digital era and joining both local and global communities related to teachers profession.

\section{References}

[1] ChaerumanUwes A., Pembelajaranabad 21, Seminar Nasional Pembelajaran Abad 21 Pusdiklat Abad Kemendikbud,http://simpatik.belajar.kemdikbud.go.id/uploads/materi-seminar/Pembelajarandi-Era-Abad-21.pdfSawangan April 2018, diakses 03 November 2019.

[2] DaryantodanSyaiful Karim, Pembelajaran Abad 21, Yogyakarta: Gava Media, 2017.

[3] HuseinLatifa, Profesi Keguruan, Menjadi Guru Profesional, Yogyakarta: PustakaBaru Press, 2017.

[4] I Wayan Redhana, Mengembangkan Keterampilan abad ke-21 dalam Pembelajaran kimia, https://journal.unnes.ac.id/nju/index.php/JIPK/article/download/17824/8934, JurnalInovasiPendidikan Kimia, Vol 13, No 1, 2019, p. 2239 - 2253, diakses 03 November 2019.

[5] Sujarwo, Pendidikan Di Indonesia Memprihatinkan https://journal.uny.ac.id/index.php/wuny /article/download /3528/pdf, diakses 03 November 2019.

[6] Shidarta, Plagiarism: Copyright Infringement (Part 3 of 3 Posts), https://businesslaw.binus.ac.id/2015/04/01/plagiarism-pelanggaran-hak-cipta-bagian-3-dari-3-tulisan/, diakses 03 November 2019.

[7] Wijaya Hengkidkk, The Development of STAD Type Cooperative Learning Model Based on Sosial Media, https://ojs.sttjaffray.ac.id/index.php/JJV71/article/view/302JurnalJaffray, Vol. 16 No. 2 (Oktober 2018). Diakses 3 Desember 2019 